\title{
Response of Castor Bean Plants to Different Row Spacings and Planting Seasons
}

\author{
Guilherme Eugênio Machado Lopes ${ }^{1}$, Henrique Duarte Vieira ${ }^{2}$, Fábio Luiz Partelli ${ }^{3}$
}

${ }^{1}$ Petrobras Biocombustível, Rio de Janeiro, Brazil; ${ }^{2}$ Laboratório de Fitotecnia, Universidade Estadual do Norte Fluminense Darcy Ribeiro, Rio de Janeiro, Brazil; ${ }^{3}$ Departamento de Ciências Agrárias e Biológicas, Centro Universitário Norte do Espírito Santo, Universidade Federal do Espírito Santo, São Mateus, Brazil.

Email: partelli@yahoo.com.br

Received August $20^{\text {th }}, 2013$; revised September 19 ${ }^{\text {th }}, 2013$; accepted October $15^{\text {th }}, 2013$

Copyright (C) 2013 Guilherme Eugênio Machado Lopes et al. This is an open access article distributed under the Creative Commons Attribution License, which permits unrestricted use, distribution, and reproduction in any medium, provided the original work is properly cited.

\begin{abstract}
The cultivation of the castor bean plant is prominent and important because of its potential for producing vegetable oils with special properties. However, research on cultivating castor bean plants is scarce, especially in areas with altitudes of $300 \mathrm{~m}$ or below. Moreover, the currently available cultivars have not been widely tested in Brazil. Thus, the aim of this study was to evaluate the response of the castor bean cultivar BRS Nordestina to different spacings at low altitudes during two cropping seasons. The study was conducted in the municipality of Itaocara, in the northwest Fluminense region, Brazil, which has an altitude of $60 \mathrm{~m}$. The treatments consisted of five row spacings $(1.5,2.0,2.5,3.0$ and 3.5 m) with $1 \mathrm{~m}$ between plants. The plants were cultivated in the 2007/2008 spring/summer season or in the 2008 autumn/winter season. A randomised block design with four replicates was used. The following parameters were assessed: plant height, height of insertion of primary raceme, number of racemes per plant, raceme length, number of fruits per raceme and grain yield. The spacing of $2.5 \mathrm{~m}$ between rows had the highest yield of castor beans during the two cropping seasons. The average yield of the cultivar BRS Nordestina indicates its potential for cultivation in northern Rio de Janeiro, below an altitude of $300 \mathrm{~m}$. The yield was higher during the summer cropping season. The less-dense arrangement of the plant population contributed to the cultivation of plants with more racemes in both growing seasons.
\end{abstract}

Keywords: Ricinus communis L.; Yield; Planting Season

\section{Introduction}

In 2009/2010, the production of castor beans in Brazil was 100,600 $\mathrm{t}$ over an area exceeding 150,000 ha, for an average yield of $636 \mathrm{~kg} \cdot \mathrm{ha}^{-1}$ [1]. In the state of Rio de Janeiro, the first studies on castor bean cultivation were conducted in the 1950s on the old Itaocara Seed Fields for Oilseed Plants [Campo de Sementes de Oleaginosas de Itaocara] [2], which is currently the Itaocara Experimental Station [Estação Experimental de Itaocara] of PESAGRO-RIO. Currently, castor oil is also used for energy production and in animal diets [3]. Studies by [4] show that the cultivation of this plant can have operating profits that exceed $\mathrm{R} \$ 1800.00 \mathrm{ha}^{-1} \cdot \mathrm{yr}^{-1}$.

Most castor bean plantations are located and most research studies are conducted in high altitudes because, in the past, it was recommended that these plants should only be cultivated in areas of high altitude, above $300 \mathrm{~m}$ [5]. However, with the advent of biodiesel, the cultivation of castor bean plants has become increasingly prominent, providing a new alternative for generating income and creating employment opportunities on farms, including in low-lying regions, that have shown good yields when planted at altitudes below $300 \mathrm{~m}[6,7]$. Properly selecting plant arrangements can improve the amount of solar radiation captured, water and nutrient use and management that the plants receive, factors that are closely related to crop yield [8].

Correctly defining plant populations is a cultural practice that has a great impact on yield and various other aspects of farming. In determining plant populations, the climate, soil characteristics, the cultivar to be planted and 
the management style to be employed all must be considered [9-12]. Highly fertile or adequately fertilised soils and water availability conditions can result in the lush growth of castor bean plants, leading to plant lodging and hindering management and harvesting operations and the final yield [11].

Currently, the recommendations addressing the spacing of castor bean plants are quite generalized [9,11]. Different spatial arrangements have been studied; however, scientific studies have focused on the northern region of Brazil [13] or regions with an altitude of $450 \mathrm{~m}$ [14] or $740 \mathrm{~m}[4,15,16]$. Thus, the availability of scientific information is scarce for the support of technical recommendations addressing the ideal populations and correct spacing between rows and between plants that should be adopted for the cultivation of castor bean plants according to regional peculiarities, especially in regions below $300 \mathrm{~m}$.

The cultivars currently available have not been widely tested in Brazil, and an understanding of their agronomic characteristics may allow the dissemination of technologies appropriate for each region [17].

There is therefore a need for experiments that address the spacing of castor bean plants in regions with altitudes less than $300 \mathrm{~m}$. The objective of this study is to determine the agronomic response of the cultivar BRS Nordestina to different spacings to optimise the grain yield of castor beans in low-altitude regions.

\section{Materials and Methods}

The experiment was conducted at the PESAGRO-RIO Experimental Station in the Itaocara municipality, State of Rio de Janeiro, northwest Fluminense region, Brazil, which is situated at an altitude of $60 \mathrm{~m}\left(21^{\circ} 40^{\prime} 09^{\prime \prime} \mathrm{S}\right.$, $\left.42^{\circ} 04^{\prime} 34^{\prime \prime} \mathrm{W}\right)$. This region has an average annual precipitation of approximately $1,000 \mathrm{~mm}$, which is concentrated during the period between October-November and MarchApril, and a mean annual temperature of $22.5^{\circ} \mathrm{C}$ [18]. During the testing period, some portions of the climate data were similar to the historical average. The rainfall recorded during the experimental period was $1,178 \mathrm{~mm}$, $1148 \mathrm{~mm}$ of which fell between October 2007 and April 2008 during the first growing season and $486 \mathrm{~mm}$ of which fell between February and August 2008 during the second experimental period (Figure 1). The rain, though irregular during the second period, was sufficient for plant development.

The treatments consisted of five row spacings $(1.5,2.0$, $2.5,3.0$ and $3.5 \mathrm{~m}$ ), with a fixed distance of $1 \mathrm{~m}$ between plants for a total population density of $6667,5000,4000$, 3333 and 2857 plants per $\cdot \mathrm{ha}^{-1}$, respectively. The crops were planted in the spring-summer period in 2007/2008 (first season) and the autumn-winter period in 2008 (second season). The experimental design consisted

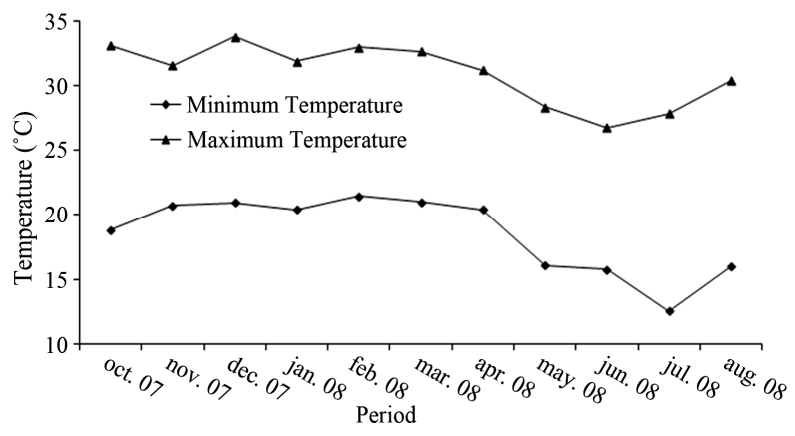

(a)

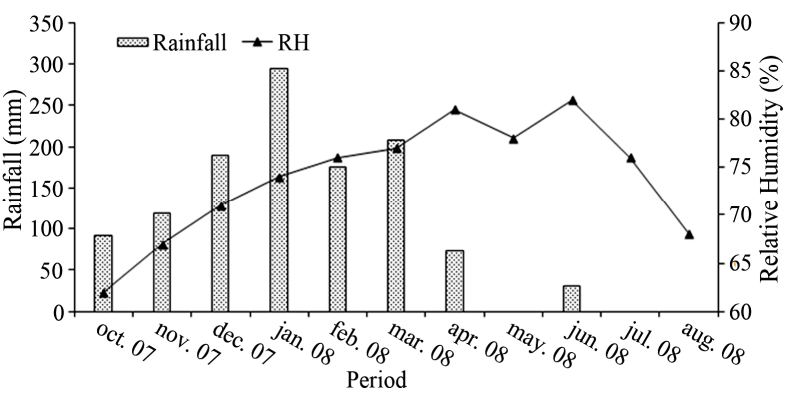

(b)

Figure 1. Averages of the maximum and minimum of the local atmospheric temperatures (a) and relative humidity and total precipitation (b) recorded at the Meteorological Station in Itaocara, RJ, Brazil during the 2007/2008 experimental period.

of a randomised block design with four replicates. The experimental plots were composed of 6-m-long and 10$\mathrm{m}$-wide rows with variations for some treatments, namely, $10.5-\mathrm{m}$-wide rows in the $3.5-\mathrm{m}$ spacings and 9$\mathrm{m}$-wide rows in the 1.5 and $3 \mathrm{~m}$ spacings. The first and last rows of each plot were designated as the borders, eliminating $1 \mathrm{~m}$ from the edges of the plot.

The soil in the study area is classified as alluvial, clayey and flat terrain. The 0 - to $20-\mathrm{cm}$ layer has a $\mathrm{pH}$ of $5.7,1.16 \mathrm{dag} \cdot \mathrm{kg}^{-1}$ of organic matter, $2.0 \mathrm{mg} \cdot \mathrm{kg}^{-1}$ of $\mathrm{P}$ (Mehlich 1 extraction method) and $45 \mathrm{mg} \cdot \mathrm{kg}^{-1}$ of $\mathrm{K}$. The $\mathrm{Ca}, \mathrm{Mg}, \mathrm{Al}$, ( $\mathrm{H}$ and $\mathrm{Al})$ concentrations, sum of bases and cation exchange capacity at $\mathrm{pH} 7$ were $1.8,2.6,0.0,2.1$, 4.6 , and $6.3 \mathrm{cmolc} \cdot \mathrm{dm}^{-3}$, respectively, with $73 \%$ base saturation. Castor bean plants are extremely sensitive to Al toxicity, and better plant development is achieved when grown in soils with a pH between 5.0 and 6.5 [19]. The $\mathrm{P}$ content was considered very low, and the $\mathrm{K}, \mathrm{Ca}$ and $\mathrm{Mg}$ content was considered high [20]. There were no impediments to plant growth in terms of Al toxicity or high acidity; thus, only adjustments with respect to fertilization were required. Following the recommendations of [21], $300 \mathrm{~kg} \cdot \mathrm{ha}^{-1}$ of a $02-30-10$ formulation (NPK) was used at planting, and $100 \mathrm{~kg} \cdot \mathrm{ha}^{-1}$ of ammonium sulphate was used $30 \mathrm{~d}$ after emergence. Weed control was accomplished through manual weeding. The field was not irrigated. 
The cultivar BRS Nordestina was sown during two different seasons, October 2007 (first season) and March 2008 (second season). Three seeds per hole were used for subsequent thinning, leaving one plant per hole. In the area used in each plot, five plants were selected at random, from which the following variables were evaluated: plant height $(\mathrm{PH})$, insertion height of the primary raceme (HPR), number of racemes per plant (NR), length of the racemes (LR) and number of fruits per raceme (NF). Grain yield (GY) was assessed for all plants in each plot after picking and weighing the fruit and converting the weight to the grain weight using the correction factor 0.6124 , as suggested by [22].

All data were analysed by regression analysis using the procedures in the program Genes [23].

\section{Results and Discussion}

The analysis of variance (data not shown) showed that the treatments had a significant effect $(p<0.01)$ on plant height, insertion height of the primary raceme, number of racemes per plant, number of fruits per raceme and grain yield in the first season, as well as the plant height, number of racemes per plant and grain yield in the second season. There were also differences between the planting seasons. Thus, to better interpret the results, an association between the characteristics evaluated and the row spacing between castor bean plants was performed for both cropping seasons (Figures 2 and 3).
In the spring/summer planting (first cropping season), the height of the castor bean plants was greater in the smaller spacings and decreased as the spacing between the rows increased. The means adjusted to a significant quadratic regression (Figure 2(a)), which is consistent with data reported by [13] for experiments conducted in Tocantins, Brazil. The insertion height of the primary raceme had the same trend with a decreasing linear effect (Figure 2(b)), which might be because of a competition effect for light in the smaller spacings combined with other environmental factors such as water availability during the period, which favoured vegetative growth in the more widely spaced plants. The trend that smaller spacings (higher density) favoured a greater insertion height of the primary raceme has also been reported by $[13,14,16]$.

In the autumn/winter planting (second growing season), the castor bean plants were shorter when grown in smaller spacings (Figure 3(a)). This effect is opposite of what was observed during the summer and might be because of increased competition between plants in the smaller row spacings, compounded by reduced water availability during this period (Figure 1). [10] reported similar results for this same cultivar under the semi-arid conditions of the northeast, consisting of low and erratic rainfall. These authors also reported that the height of the castor bean plant was directly related to the availability of water during the growing cycle, which was lower per

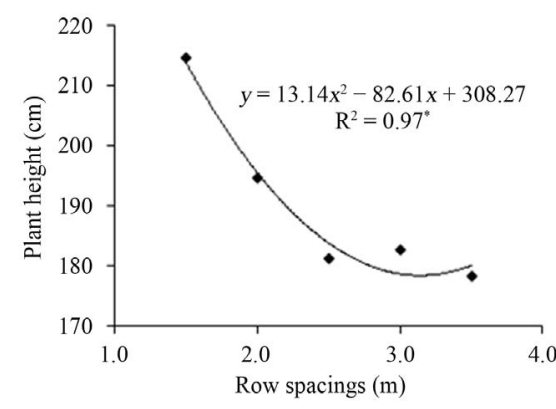

(a)

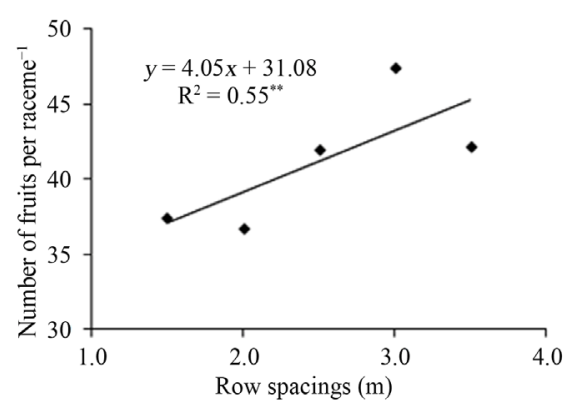

(d)

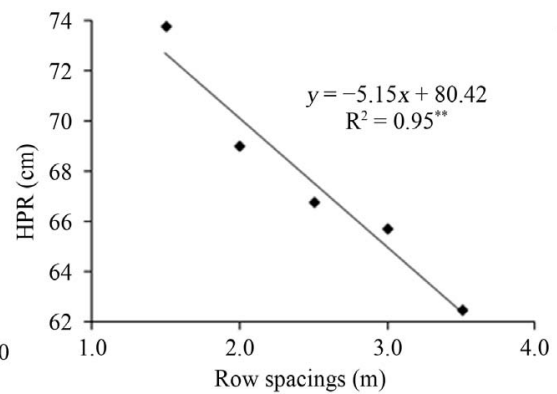

(b)

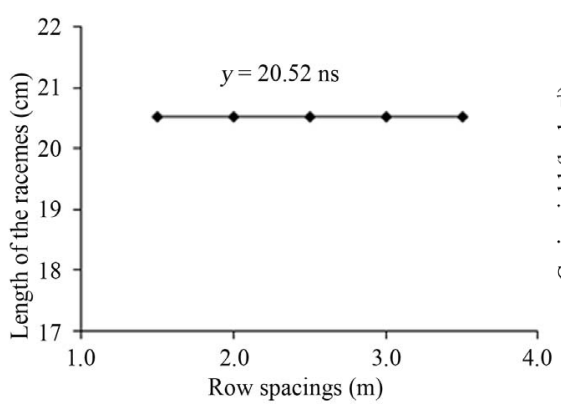

(e)

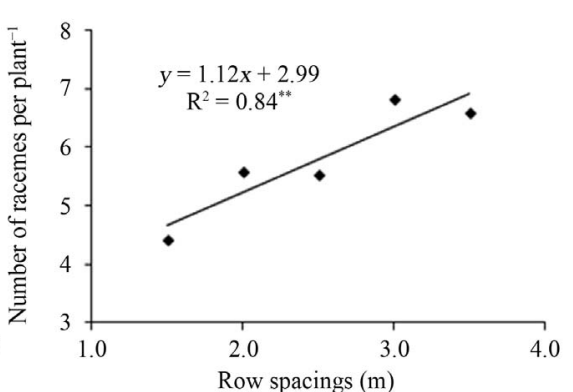

(c)

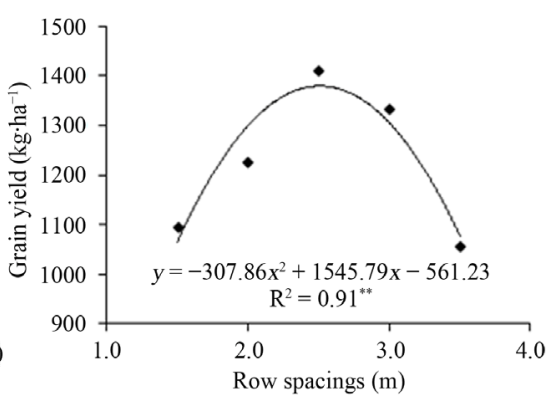

(f)

Figure 2. Plant height (a), insertion height of the primary raceme-HPR (b), number of racemes per plant (c), number of fruits per raceme (d), length of the racemes (e) and grain yield (f) of the BRS Nordestina cultivar of castor beans as a function of spacing during the summer cropping season. 


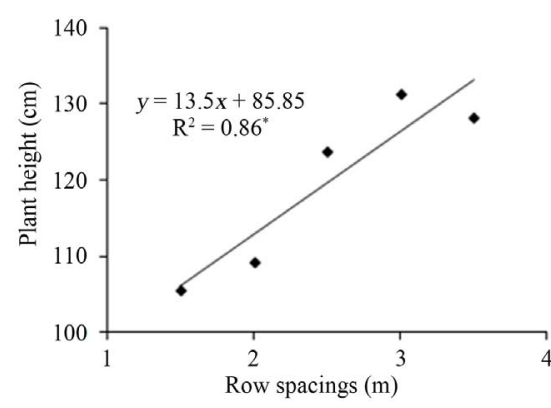

(a)

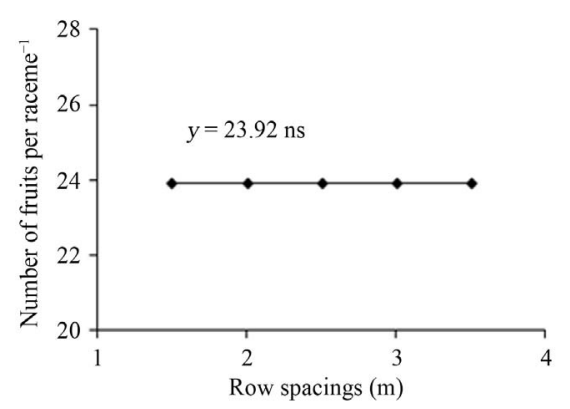

(d)

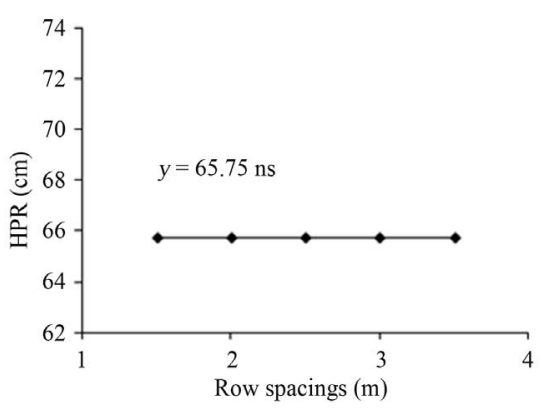

(b)

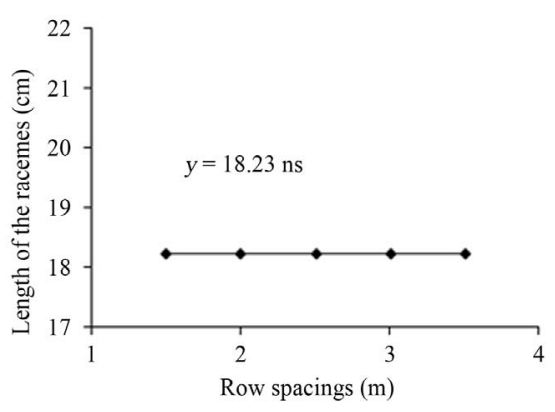

(e)

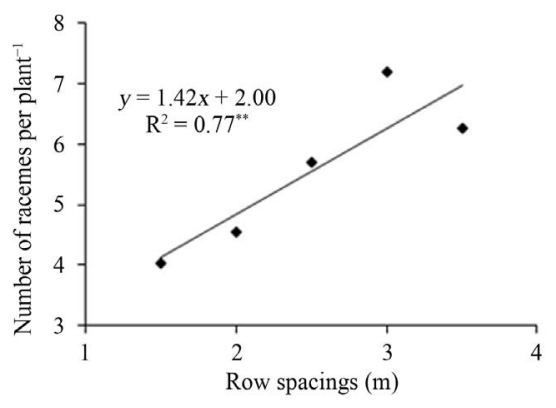

(c)

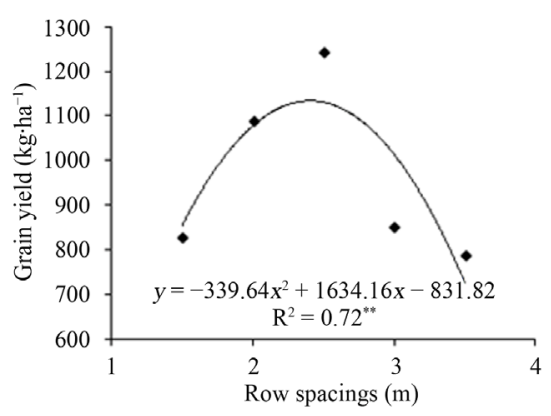

(f)

Figure 3. Plant height (a), insertion height of the primary raceme-HPR (b), number of racemes per plant (c), number of fruits per raceme (d), length of the racemes (e) and grain yield (f) of the BRS Nordestina cultivar of castor beans as a function of spacing during the winter cropping season.

plant when planted more densely. Spacing did not have a significant effect on the insertion height of the primary raceme in the winter season (Figure 3(b)).

For characteristics associated with production, the different spacings had a significant effect on several of the study variables during both cropping seasons (Figures 2 and 3). The number of racemes per plant during the cropping seasons increased linearly such that the number of racemes increased as the row spacing increased (Figures 2(c) and 3(c)). This increase is most likely associated with the increased amount of light and greater space available for plant development, thus allowing more racemes to emerge. [14-16] described similar trending results for the cultivation of castor bean plants at higher altitudes. The number of fruits per raceme in the autumn/ winter season was not influenced by the row spacing (Figure 3(d)). However, in the spring/summer season, as the spacing of the castor bean plants increased, the number of fruits per raceme increased linearly (Figure 2(d)), which is consistent with results reported by $[15,16]$. With more area per plant, the plants tended to develop more, as there was less competition for nutrients, water and light, resulting in a higher number of racemes per plant cultivation during both the summer and winter plantings and a higher number of fruits per raceme during the summer planting.

The variation in spacing did not influence the length of the racemes during either cropping season (Figures 2(e) and 3(e)). This observation was also reported by [13], indicating that this characteristic is intrinsic to the cultivar and is hardly influenced by the environment.

There was a quadratic effect of spacing on grain yield in both cropping seasons, with the highest yields being produced at a spacing of $2.5 \mathrm{~m}$, which corresponds to a population of 4,000 plants'ha ${ }^{-1}$ and yields of 1,411 $\mathrm{kg} \cdot \mathrm{ha}^{-1}$ during the first season (Figure 2(f)) and 1,243 $\mathrm{kg} \cdot \mathrm{ha}^{-1}$ during the second season (Figure 3(f)). These yields are well above the national average of $636 \mathrm{~kg} \cdot \mathrm{ha}^{-1}$ in Brazil [1] and are higher than in other regions of the country [7]. However, these yields are similar to yields generated in irrigated areas at altitudes above $500 \mathrm{~m}$ [24].

The reduced yield in the narrower spacings may be associated with competition between plants, as evidenced by the smaller number of racemes per plant. Conversely, the yield decreased in the largest spacings due to a smaller plant population, resulting in an underutilisation of the area. Thus, although the number of racemes per plant increased as the row spacing increased, the reduction of the number of plants per hectare had a more significant influence on the yield.

The results for the maximum yield were very similar between the two cropping seasons, indicating that a spacing of approximately $2.5 \mathrm{~m}$ (and $1 \mathrm{~m}$ between plants) is the most suitable spacing for the cultivar BRS Nordestina under the experimental conditions used in this study. These results are consistent with the information reported in other studies conducted in northeast Brazil, including [11], who reported maximum yields at spacings between 
2 and $2.4 \mathrm{~m}$ for the cultivar BRS Nordestina. The springsummer cultivation season produced higher yields than the autumn-winter season (Figures 2(f) and 3(f)). This difference in yield is associated with climate issues such as precipitation and temperature, which are more favourable during the spring-summer season (Figure 1) and consequently resulted in greater plant heights, as also reported by [25], and a greater number of fruits per raceme (Figures 2(a), (d) and 3(a), (d)).

In the semiarid Paraiba region (Brazil), [26] reported that, by the end of the vegetative stage (approximately seventy days after germination), precipitation levels of 215 and $270 \mathrm{~mm}$ during two years of cultivation were sufficient to ensure the production of well-established and productive plants. [25] performed several experiments to evaluate four planting seasons combined with different irrigation management schemes in Ceará, Brazil. These experiments indicated that castor bean plants most likely use the available water supply efficiently at the beginning of the cycle and then succeed in securing good yields even after the end of the rainy season or after irrigation has ended. However, higher yields can be achieved when there is more rainfall or adequate irrigation management. The studies conducted by [4] show that the yield and profitability of castor beans can differ between cultivars and planting years.

\section{Conclusion}

The highest yield of castor beans during the two cropping seasons was produced at a spacing of $2.5 \mathrm{~m}$ between rows, yielding a population of 4000 plants ha ${ }^{-1}$. The average yield of the cultivar BRS Nordestina highlights the potential yield of castor beans in the northern region of Rio de Janeiro below an altitude of $300 \mathrm{~m}$. The less dense population arrangement resulted in plants with a higher number of racemes during both growing seasons.

\section{REFERENCES}

[1] Conab-Companhia Nacional de Abastecimento, "Série Histórica: Mamona," 2013. http://www.conab.gov.br/conteudos.php?a=1252\&t=2\&P agina_objcmsconteudos=2\#A_objcmsconteudos

[2] C. Bayma, "Mamona," Ministério da Agricultura, Serviço de Informação Agrícola, Rio de Janeiro, 1958, 96 Pages.

[3] R. N. Furtado, M. S. S. Carneiro, M. J. D. Cândido, F. H. T. Gomes, E. S. Pereira, R. C. F. F. Pompeu and W. A. Sombra, "Valor Nutritivo de Dietas Contendo Torta de Mamona Submetida a Métodos Alternativos de Destoxificação Para Ovinos," Arquivo Brasileiro de Medicina Veterinária e Zootecnia, Vol. 64, No. 1, 2012, pp. 155162.

[4] R. A. Petinari, R. P. Soratto, G. D. Souza-Schlick, M. D. Zanotto and S. M. P. P. Bergamasco, "Custos de Produção e Lucratividade de Cultivares de Mamona em diferentes Arranjos de Plantas," Pesquisa Agropecuária Tropical, Vol. 42, No. 2, 2012, pp. 143-149. http://dx.doi.org/10.1590/S1983-40632012000200004

[5] N. E. M. Beltrão, "A Cadeia da Mamona no Brasil, Com Ênfase Para o Segmento P\&D: Estado de Arte, Demandas de Pesquisa e Ações Necessárias Para o Desenvolvimento," Empresa Brasileira de Pesquisa Agropecuária (EMBRAPA-CNPA), 2004, 19 p. (Doc. 129).

[6] L. S. Severino, C. R. A. Moraes, T. M. S. Gondim, G. D. Cardoso and N. E. M. Beltrão, "Crescimento e Produtividade da Mamoneira Influenciada por Plantio em Diferentes Espaçamentos entre Linhas," Revista Ciência Agronômica, Vol. 37, No. 1, 2006c, pp. 50-54.

[7] M. A. Diniz Neto, I. F. Silva, L. M. T. Diniz, A. A. Pereira and A. R Pereira, "Componentes de Produção de Mamona em Função de Níveis de Adubação Nitrogenada e Desfolha," Revista Ciência Agronômica, Vol. 43, No. 3, 2012, pp. 546-553.

http://dx.doi.org/10.1590/S1806-66902012000300018

[8] G. Argenta, P. R. F. Silva, C. G. Bortolini, E. L. Forsthofer, E. A. Manjabosco and V. B. Neto, "Resposta de Híbridos Simples de Milho à Redução do Espaçamento Entre Linhas," Pesquisa Agropecuária Brasileira, Vol. 36, No. 1, 2001, pp. 71-78.

http://dx.doi.org/10.1590/S0100-204X2001000100009

[9] W. V. Cartaxo, N. E. M. Beltrão, O. R. R. F. Silva, L. S. Severino, N. D. Suassuna and J. J. Soares, "O Cultivo da Mamona no Semi-Árido Brasileiro,” Empresa Brasileira de Pesquisa Agropecuária (Embrapa Algodão), 2004, 20 p. (Circular Técnica, 77).

[10] L. S. Severino, D. K. Coelho, C. R. A. Moraes, T. M. S. Gondim and L. S. Vale, "Otimização do Espaçamento de Plantio Para a Mamoneira Cultivar BRS Nordestina," Revista Brasileira de Oleaginosas e Fibrosas, Vol. 10, No. 1-2, 2006, pp. 993-999. http://www.scielo.br/pdf/brag/v70n3/a06v70n3.pdf

[11] L. S. Severino, G. B. Ferreira, C. R. A. Moraes, T. M. S. Gondim, W. S. A. Freire, D. A. Castro, G. D. Cardoso and N. E. M. Beltrão, "Crescimento e Produtividade da Mamoneira Adubada com Macronutrientes e Micronutrientes," Pesquisa Agropecuária Brasileira, Vol. 41, No. 4, 2006, pp. 563-568.

http://dx.doi.org/10.1590/S0100-204X2006000400003

[12] D. Tajima, A. Kaneko, M. Sakamoto, Y. Ito, N. T. Hue, M. Miyazaki, Y. Ishibashi, T. Yuasa and M. Iwaya-Inoue, "Wrinkled 1 (WRI1) Homologs, AP2-Type Transcription Factors Involving Master Regulation of Seed Storage Oil Synthesis in Castor Bean (Ricinus communis L.)," American Journal of Plant Sciences, Vol. 4, No. 2, 2013, pp. 333-339. http://dx.doi.org/10.4236/ajps.2013.42044

[13] E. V. Carvalho, C. H. A. C. Sá, J. L. Costa, F. S. Afférri and S. C. Siebeneichler, "Densidade de Plantio em Duas Cultivares de Mamona no Sul do Tocantins," Revista Ciência Agronômica, Vol. 41, No. 3, 2010, pp. 387-392. http://dx.doi.org/10.1590/S1806-66902010000300010

[14] T. K. M. C. Bizinoto, E. G. Oliveira, S. B. Martins, S. A. Souza and M. Gotardo, "Cultivo da Mamoneira Influenciada por Diferentes Populações de Plantas," Bragantia, Vol. 69, No. 2, 2010, pp. 367-370. 
http://dx.doi.org/10.1590/S0006-87052010000200014

[15] R. P. Soratto, G. D. Souza-Schlick, B. M. S. Giacomo, M. D. Zanotto and A. M. Fernandes, "Espaçamento e População de Plantas de Mamoneira de Porte Baixo Para Colheita Mecanizada," Pesquisa Agropecuária Brasileira, Vol. 46, No. 3, 2011, pp. 245-253.

http://www.scielo.br/pdf/pab/v46n3/a04v46n3.pdf

[16] G. D. Souza-Schlick, R. P. Soratto, C. B. Pasquali and A. M. Fernandes, "Desempenho da Mamoneira IAC 2028 em Função do Espaçamento Entre Fileiras e População de Plantas na Safrinha," Bragantia, Vol. 70, No. 3, 2011, pp. 519-528.

[17] J. Zuchi, G. A. P. Bevilaqua, J. C. Zanuncio, S. T. Peske, S. D. A. Silva and C. S. Sediyama, "Características Agronômicas de Cultivares de Mamona em Função do Local de Cultivo e da éPoca de Semeadura no Rio Grande do Sul," Ciência Rural, Vol. 40, No. 3, 2010, pp. 501-506. http://dx.doi.org/10.1590/S0103-84782010000300001

[18] L. F. G. Oliveira Júnior, M. G. Pereira and R BressanSmith, "Caracterização e Avaliação Agronômica de Híbridos e Linhagens de Milho Doce," Horticultura Brasileira, Vol. 24, No. 3, 2006, pp. 283-288. http://dx.doi.org/10.1590/S0102-05362006000300003

[19] M. S. Amorim Neto, A. E. Araújo and N. E. M. Beltrão, "Clima e Solo," In: D. M. P. Azevedo and E. F. Lima Eds., O agronegócio da Mamona No Brasil, Embrapa Algodão, Campina Grande, Embrapa Informação Tecnológica, Brasília, 2001, pp. 63-74.

[20] B. Van. Raij, H. Cantarella, J. A. Quaggio and A. M. C, Furlani, "Recomendações de Adubação e Calagem Para o Estado de São Paulo," 2nd Edition, Instituto Agronômico,
Fundação IAC, Campinas, 1997, 285 Pages.

[21] A. S. Filho, "Mamona," In: B. Van Raij, H. Cantarella, J. A. Quaggio and A. M. C. Furlani, Recomendações de Adubação e Calagem Para o Estado de São Paulo, 2nd Edition, Instituto Agronômico/Fundação IAC, Campinas, 1997, p. 201.

[22] L. S. Severino, C. R. A. Moraes, T. M. S. Gondim, G. D. Cardoso and J. W. Santos, "Fatores de Conversão do Peso de Cachos e Frutos Para Peso de Sementes de Mamona," Empresa Brasileira de Pesquisa Agropecuária (Embrapa Algodão), 2005, 15 p. (Boletim de Pesquisa e Desenvolvimento, 56).

[23] C. D. Cruz, "Programa Genes-Versão Windows: Aplicativo Computacional em Genética e Estatística," Ed. UFV, Viçosa, 2006, 648 Pages.

[24] G. A. Biscaro, M. A. B. Vaz, G. M. Giacon, E. P. Gomes, S. B. Silva and A. V. A. Motomiya, "Produtividade de Duas Cultivares de Mamona Submetidas a Diferentes Lâminas de Irrigação Suplementar," Revista Brasileira de Engenharia Agrícola e Ambiental, Vol. 16, No. 9, 2012, pp. $925-930$. http://dx.doi.org/10.1590/S1415-43662012000900001

[25] A. S. Souza, F. J. A. F. Távora, J. B. Pitombeira and F. M. S. L. Bezerra, "Épocas de Plantio e Manejo da Irrigação Para a Mamoneira. II-Crescimento e Produtividade," Revista Ciência Agronômica, Vol. 38, No. 4, 2007, pp. 422-429.

[26] D. M. P. Azevedo, N. E. M. Beltrão and F. A. S. Batista, "Arranjo de Fileiras no consóRcio Mamona/Milho," Empresa Brasileira de Pesquisa Agropecuária (EMBRAPA-CNPA), 1997, 52 Pages. (Boletim de Pesquisa, 34). 